This item was submitted to Loughborough's Research Repository by the author.

Items in Figshare are protected by copyright, with all rights reserved, unless otherwise indicated.

\title{
The factory that became a village: the history of the Royal Small Arms Factory at Enfield lock
}

\section{PLEASE CITE THE PUBLISHED VERSION}

https://doi.org/10.1080/17581206.2020.1840951

\section{PUBLISHER}

Informa UK Limited, trading as Taylor \& Francis Group

\section{VERSION}

AM (Accepted Manuscript)

\section{PUBLISHER STATEMENT}

This is an Accepted Manuscript of an article published by Taylor \& Francis in The International Journal for the History of Engineering \& Technology on 12 November 2020, available online:

http://www.tandfonline.com/10.1080/17581206.2020.1840951.

\section{LICENCE}

CC BY-NC-ND 4.0

\section{REPOSITORY RECORD}

Williams, David. 2020. "The Factory That Became a Village: The History of the Royal Small Arms Factory at Enfield Lock”. Loughborough University. https://hdl.handle.net/2134/13288736.v1. 
The Factory That Became a Village, The History of the Royal Small Arms Factory of Enfield Lock, By JIM LEWIS. Pp 160, approximately 170 black and white illustrations. Faringdon, Oxfordshire: Redshank Books, 2019. £18. Softback. ISBN 978-0-9954834-4-6.

This book covers the history of The Royal Small Arms Factory (RSAF) at Enfield lock from its foundation to its close in 1988 and the subsequent regeneration of its site as an island village with the former large machine room of the mid- $19^{\text {th }}$ century factory with its ancient clock as the village centre piece. The author is recognised as an authority on the history and development of Greater London's Lea Valley and the book has been published with the support of the RSA Trust. It was envisaged to cover the history of the RSAF and its site from its birth in 1816 until today and to be made up of short chapters. It is presented as three parts. The first of over 90 pages focusses on the context of the factory built in the 1850's using largely American technology to permit the interchangeable large-scale manufacturing of the Pattern 1853 muzzle loading rifle-musket and a technological first in Britain. The second part of almost 30 pages takes the factory and the weapons that it produced from the Crimea to its closure and the third part, again of almost 30 pages, tells the story of its redevelopment as a village including the preservation of key features of the old industrial site.

It draws upon two earlier histories of the RSAF. One is the important but limited circulation work 'A Short History of the Royal Small Arms Factory Enfield' by Tim Putnam and Dan Weinbren with the assistance of others including the author of this work and commissioned by Royal Ordnance plc part of British Aerospace Defence and published in 1992. The other is the later 1998 book by David Pam, Enfield local historian, 'The Royal Small Arms Factory Enfield \& Its Workers'. These in turn drew on earlier unpublished efforts including that likely to have been written by $\mathrm{G} H$ Roberts, Enfield Superintendent between 1921 and 1931, in 1930-31. Part One of the book also significantly draws upon the author's unpublished $1996 \mathrm{PhD}$ thesis (https://eprints.mdx.ac.uk/6706/1/Lewis.phd.pdf ) with Part Two drawing on other of his publications. It is disappointing that there few references to recent scholarship on Enfield and on interchangeability and that some of the illustrations are small. When considering the Enfield factory, and thus this book, we need to keep in mind that interchangeable manufacturing and its role in mass production is still understood as being one of the key enablers of the modern economy and that methods to achieve it have long held the attention of scholars in the history of technology and will continue to do so.

In only a few pages chapter one of Part One of the book quickly jumps from the original 1815 developments on the Enfield lock site (for recent scholarship on this see Williams and Harding 2018) to the construction of the new factory between 1855 and 1859 following the exploration of American methods of manufacturing small arms, subsequently labelled 'The American System'. Subsequent extended chapters expand on the small arms industry between 1840 and 1854 particularly using evidence presented to the Select Committee on Small Arms in 1854. These highlight the role of the Enfield Storekeeper, George Lovell, who subsequently became the Inspector of Small Arms in 1840 and was the dominant influencer of small arms design during the percussion muzzle loading era. They describe the tensions between the Board and Ordnance and the London and Birmingham gun trades because of their strictness of view (inspection) when compared with that of other major customers such as the East 
India Company which were further exacerbated by actions by Lovell that constrained the supply of key gauges to the suppliers. They also present the issues of the necessary scale up of the supply of weapons in time of war that are inevitably experienced by governments not willing to invest until forced to by circumstances and a lack of understanding of the engineering issues and lead time associated with constructing the necessary manufacturing capacity by the Ordnance and other officials. As described the consequences of this were ultimately the building of interchangeable Pattern 1853 rifle-muskets in the new factory in Enfield from 1857 by "revolutionary methods" with consequent changes in working practice. This was accompanied by the construction of similar capacity in the gun trade in London and subsequently in Birmingham by the consortium of gun makers that formed Birmingham Small Arms to make guns by machine.

The closing chapter, six, of this part of the book, together with some earlier material discusses the role of machines and skills in gunmaking. It attempts to clarify "the debate on what effect the introduction of the system of interchangeability by standardised machine-made parts had on the traditional skills of the artisan" given that "arguments range from the complete de-skilling of the workforce to the opposite extreme of improving skills and status". It highlights the requirement, even with the application of large numbers of machines and gauges, for hand finishing (filing) in the interchangeable manufacturing of small arms. It particularly attempts to gather evidence of the differences in performance between the Enfield site, using a small and restricted sample of locks and gauges, and Springfield Armory, as established by Robert Gordon of Yale University, to enable the reader to draw their own conclusions on the hand skills necessary to deliver component interchangeability in Britain and America with the implication that the requirement for hand finishing lingered longer in the US. The reader should however understand when reviewing the material presented that technically all dimensions were not required to be interchangeable and that some fits were hand finished, for instance the lapping of the tumbler to lock plate bearing surfaces, to achieve the necessary fit required for product performance. The reader should also consider that the world of $18^{\text {th }}$ and $19^{\text {th }}$ century volume military artisanal manual gunmaking particularly of forged and filed metal components was not a cosy 'arts and crafts' world, or the world of best gunmaking in London, most of it would be represented by the unbelievably squalid, frequently the same, working and living conditions of the Birmingham and Black Country, and Liege metals industry outworker.

Part two of the book sketches the history of the RSAF and the weapons it produced from the 1850's in five short chapters. The first of these spans from the Crimea to the Great War and touches on the Pattern 1853 rifle and its Snider breech loading conversion, the Lee Enfield magazine breech loader and its variants including the SMLE Mark III, and the development of the Pattern 1914 and its American variant the Model 1917, these both produced in volume in the US. Surprisingly there is little discussion of the Martini-Henry, the weapon of the high Victorian Empire and the first purpose built single shot breech loader, particularly significant to the development of Enfield because it required the building of a large and well-equipped forge. The second chapter of this section covers the interwar period and the licensing of the factory to produce the light machine gun designed by Vaclav Holek of the Zbrojovka Brno Factory and chambered for the British 0.303 " round. This, the Bren, with its name derived from a combination of the names of the two factories Brno and Enfield, and its 
volume manufacture at Enfield was subsequently particularly important to the British war effort because of its role as a section weapon in World War Two. The next chapter of this section spans scale up of manufacture from the start of World War Two at Enfield and its sister plants, including that of the simplified No 4 variant of the Lee Enfield and the Enfield revolver, to the ultimate closure of the factory in 1988. Perhaps the most significant weapon developed during the war at Enfield was the Sten gun, a straightforward to make personal automatic weapon that was made at scale in workshops all over Britain. The post war story is one of a changing, increasingly design led, role for the site as post-Imperial Britain struggled to work with its NATO allies on the next generations of personal and other weapons including the small bore Enfield Weapon System ultimately chambered for the $5.56 \mathrm{~mm}$ round and becoming the SA80. The dynamics of this innovation process have been explored by Matthew Ford (Ford 2017), an instance of the academic in-depth study of the defence procurement process identified here by Dr Lewis as being required. As is described in the final two chapters of this section, the site finally closed in 1988 after its purchase by British Aerospace with all production transferred to the Royal Ordnance plc factory at Nottingham together with the Enfield Pattern Room Collection, fortunately saved as a whole. It should perhaps be emphasised that, while this part of the book is brief, there is a large complementary literature on the weapons produced by Enfield.

The closing part three of the book is perhaps its most distinctive component to those interested in the preservation of technological sites. The first chapter traces the troubled path from early attempts to redevelop the site to plans that became progressively more centred on its residential use. Plans stabilised as green belt restrictions were lifted and local authority boundaries changed, and with changes in the ownership of the site. During this seven to eight year period of uncertainty, the site and its buildings were deteriorating, including the most distinctive, and listed building on the site, the large machine room built in 1856. In the second and third chapters of this part of the book the reader is introduced to the four founders of the RSA Trust project, Michael Polledri, Martin Jewell, and Mike Wehrman of the Enfield Enterprise Agency, and Gary Walker, subsequently Trust Chairman. These successful business people were ready to give something back as the Trust took on the project of redeveloping the large machine room as a hub for the new community. This required the creation of a vision - initially for shops and units for small businesses and later extended to encompass community and youth centres, a health centre and an interpretation centre showing the history of the site - supported by a realistic business plan and energetic fund raising to secure the $£ 4$ million necessary to realise the plan. The following chapters describe some of the practical issues associated with the development of a mildly contaminated brown field site, decisions on which buildings could and should be practically preserved and getting on with the job of demolition, restoration and new build of the RSA Island Centre. An important chapter shows how particular buildings and features of the overall site including its $18^{\text {th }}$ century clock have been preserved to retain some of its distinctive character and how this has been supported by the wider "Lockie" community and members of the RSAF Enfield Apprentices Association. The book closes with an account of the opening of the RSA Island Centre in 2001 and the subsequent management of the initiative including the population of the units with appropriate small businesses and other organisations, some of which are described in an appendix. A conclusion highlights the risks of relying on overseas suppliers for small arms but reinforces the impact of the not-for-profit 
project that turned the core of the site into a community hub and recommends it as an exemplar for others.

Given the considerable focus of the book on the 1850's factory, the preservation of the large machine room, and the American System as embodied in the special purpose machines installed there, from this reviewers perspective a key gap in this and all Enfield studies so far is a broad and through technical perspective on the aggregation of the essential changes made there discreetly in the 1920's and their impact. In spite of both the US and UK arsenals and others largely working as well as they could with the ways of working they had, the American system as implemented in gunmaking ran out of steam in the Great War. Because of its insular nature it had not kept pace with changes in engineering practice and this was further exacerbated by intense day to day pressures and skill shortages due to the dilution of labour. Springfield inspectors held tolerances "under their hats", the cost of multiple gauging sets was prohibitive, and the SMLE for instance proved problematic to get produced in the US because it was not described at the right level of detail to plants that might make it. In a tough post war period that was apparently resisting military related spending the factory had time to think and implemented the learning from the Great War. It made many of the changes that really prepared the factory for World War Two. Much of this change at Enfield was made under the leadership of G H (Gervase Henry) Roberts who we have already met in this review as a historian. Roberts secured an external London degree at Yorkshire College, Leeds an antecedent of Leeds University, served an apprenticeship and spent his early career in the railway industry. He moved to the Royal Arsenal Woolwich in 1904 ultimately rising to be Chief Mechanical Engineer and joined Enfield as superintendent in 1921 retiring in 1931. Changes included: significant progressive refurbishment of machines with targets of two a week later raised to four a week; the installation of one of the first jig borers in 1921; the quiet scrapping in 1924 of the local Enfield inch standard and migration to that of the National Physical Laboratory that was recognised internationally; careful simplification of the design of the SMLE into its easier to make Mark VI variant, subsequently the number No 4 rifle, with major prototype evaluations in 1926; the retirement of the sealed Pattern system (the last UK Pattern was sealed on 22/10/26) and its replacement by toleranced component drawings; a re-layout of the large machine room completed in 1927; progressive investment in general purpose machines with a step change from 1928 and an ultimate investment of $£ 100 k-150 k$; and, in 1929 the building of a new heat treatment plant on the site of the former chapel. The change from the Enfield inch reflected the pre-Great War experience of Pratt and Whitney suppling machines to Lithgow, Australia and the struggles to make SMLE components made in Enfield and Lithgow interchange (refreshingly described in Griffiths 2003). Critically these changes ultimately meant that No 4 rifles could be made in a number of US plants and in Canada and that Brens could made at scale in Enfield.

This book is an inexpensive gateway to an understanding of the history of the RSAF for local, technological and military historians rather than a glossy coffee table book for the gun collector. It complements the 'Short History' of Putnam and Weinbren and is something of a blueprint for rescuing important factories and keeping components of them features of the landscape. There is however still so much more that could be done to better understand the Enfield factory and its influence, for instance by considering how interchangeability was achieved from a number of broader related perspectives: the manufacture of small arms with respect to the changing definitions 
and practice of interchangeability; the particular requirements of a national armoury and its need to scale up production in time of war; and the technologies that are actually required to realise such mass production approaches with statistical confidence - all of these were necessary during the life of the Enfield factory. Let us hope this new book encourages others to both take up the story of the factory and to emulate the approach of the RSA Trust to redevelop other similar important industrial sites.

\section{$\underline{\text { References }}$}

Matthew Ford (2017) Weapon of Choice, Small Arms and the Culture of Military Innovation, Hurst \& Company, London, pp 248.

Tony Griffiths (2003) The Enfield Inch and the Lithgow .303, a tale of metrology from Australian firearm folklore, Toptech Engineering, New South Wales, Australia, pp 86.

David Williams \& David Harding (2018) The Enfield Lock Barrel Mill of 1815 and Moves to Replace Musket Barrel Grinding by Turning c1780 to c1840, Arms \& Armour, 15:1, 22-57. 